\title{
INFLUENCE OF SOLUTIONS WITH PIGMENTATION POTENTIAL ON TOOTH COLOR AFTER BLEACHING USING 22\% CARBAMIDE PEROXIDE
}

\author{
INFLUÊNCIA DE SOLUÇÕES COM POTENCIAL DE PIGMENTAÇÃO NA COR \\ DOS DENTES APÓS CLAREAMENTO COM PERÓXIDO DE CARBAMIDA A 22\%
}

\author{
Ayla Macyelle de Oliveira CORREIA ${ }^{1}$; Bruno Everthon Duarte MELO²; \\ Juliana da Silva Barros CEDRAZ ${ }^{3}$; Daniel Maranha da ROCHA ${ }^{4}$; \\ Natanael Barbosa dos SANTOS ${ }^{5}$; Larissa Silveira de Mendonça FRAGOSO ${ }^{2}$
}

1. Department of Restorative Dentistry, São Paulo State University (UNESP), Institute of Science and Technology, São José dos Campos, SP, Brazil; 2. Department of Restorative Dentistry, School of Dentistry, Federal University of Alagoas, Campus AC Simões, Maceió, AL, Brazil; 3. Department of Restorative Dentistry - Universidade Federal de Sergipe, Aracaju, SE, Brazil; 4. Department of Restorative Dentistry - Universidade Federal de Sergipe, Lagarto, SE, Brazil; 5. Department of Cariology, School of Dentistry, Federal University of Alagoas, Campus AC Simões, Maceió, AL, Brazil.

\begin{abstract}
The color stability achieved by dental bleaching can be affected by exposure to staining agents present in foods. However, there is scarce research regarding tooth staining during dental bleaching. This study investigated the effect of pigments on the color stability of dental elements during dental bleaching. Blocks obtained from bovine incisors were divided into seven groups $(\mathrm{n}=10)$ in accordance with the staining pigments (distilled water - control; coffee, cola, tea, red wine, chocolate milk and soya sauce (Shoyu). The color was evaluated with a spectrophotometer (Minolta CR-321, Japan) before and after dental bleaching ( $1^{\text {st }}$ and $14^{\text {th }}$ days), employing the (CIE) $\mathrm{L}^{*} \mathrm{a}^{*} \mathrm{~b}^{*}$ system. The dental bleaching procedure was performed using $22 \%$ carbamide peroxide gel applied to the sample surface for a period of 1 hour each day, for 14 days. After dental bleaching, the teeth were exposed to $20 \mathrm{ml}$ of staining solution for 5 minutes, at $37^{\circ} \mathrm{C}$ and $100 \mathrm{rpm}$ for different periods. During the experiment, the samples were stored in distilled water. Data was analyzed using ANOVA followed by Tukey tests, with a significance level of 5\%. Significant differences for $\Delta \mathrm{E}^{*}$ values $(\mathrm{p}<0.05)$ were observed between the groups. The Shoyu group presented a decrease in luminosity (negative value of $\Delta \mathrm{L}^{*}$ ). It could be concluded that all solutions contained pigments that promoted staining on the surface. However, bleached enamel was susceptible to staining with soya sauce (Shoyu), while other substances did not interfere with the dental bleaching.
\end{abstract}

KEYWORDS: Dental materials. Color. Pigmentation. Tooth bleaching. Spectrophotometry.

\section{INTRODUCTION}

Tooth discoloration has been identified as one of the major cause of patient dissatisfaction in aesthetics. Dental element color changes occur depending on numerous factors, such as: pathophysiological darkening of the tooth (intrinsic), trauma, iatrogenic endodontic treatment and extrinsic stains from enamel/dentine (PAOLONE et al., 2013. BEDDIS; NIXON, 2012). The correct diagnosis of the cause of discoloration of teeth is of great importance because it has an influence on the treatment outcome (CÔRTES et al., 2013).

Dental bleaching is a conservative alternative that has a high success rate in for the treatment of discolored teeth (BASTING et al., 2012). Dental bleaching consists of the application of a hydrogen peroxide or carbamide-based agent in low-concentration on the surface of discolored teeth (CÔRTES et al., 2013). Dental bleaching is only possible thanks to the permeability of the tooth structure to bleaching agents, which is able to diffuse freely through the enamel and dentin and act on the organic part of these structures. Due to their low molecular weight, peroxides, when in contact with the tooth surface, release oxygen radicals through a redox reaction which is capable of breaking down the macromolecules responsible for pigmentation, promoting a whitening effect (LIMA et al., 2011. LIMA et al., 2009. JOINER, 2004).

Some studies have reported that dental bleaching can cause surface alterations in dental substrate, such as the formation of pores, enamel erosion or increase the surface roughness and microhardness (DEY et al., 2016. MOOSAVI; DARVISHZADEH, 2016. LIA MONDELLI et al., 2015; DE ABREU et al., 2011). These changes may be partly due to the loss or denaturing of protein (ZIMMERMAN et al., 2010) and facilitate the recurrence of extrinsic staining ( JOINER, 2004. NATHOO, 1997). Therefore, the color stability achieved by bleaching can be affected by exposure to staining agents present in certain types of foods 
(KARADAS; SEVEN, 2014. PIROLO et al., 2014. CÔRTES et al., 2013. LIPORONI et al., 2010. ATTIA et al., 2009). However, some studies have demonstrated that contact of the teeth with saliva for a prolonged time can avoid such discoloration (DE ABREU et al., 2011. SPALDING et al., 2003. JOSEY et al., 1996). This may be due to the remineralization process, which reverses the reduced mineral loss and consequently the enamel porosity caused by bleaching.
Since there is limited information regarding overall change in tooth color during dental bleaching, the aim of this in vitro study was to evaluate the effect pigments have and the influence of different agents on the color stability of dental elements during bleaching with carbamide peroxide.

\section{MATERIAL AND METHODS}

The study design is represented in Figure 1.

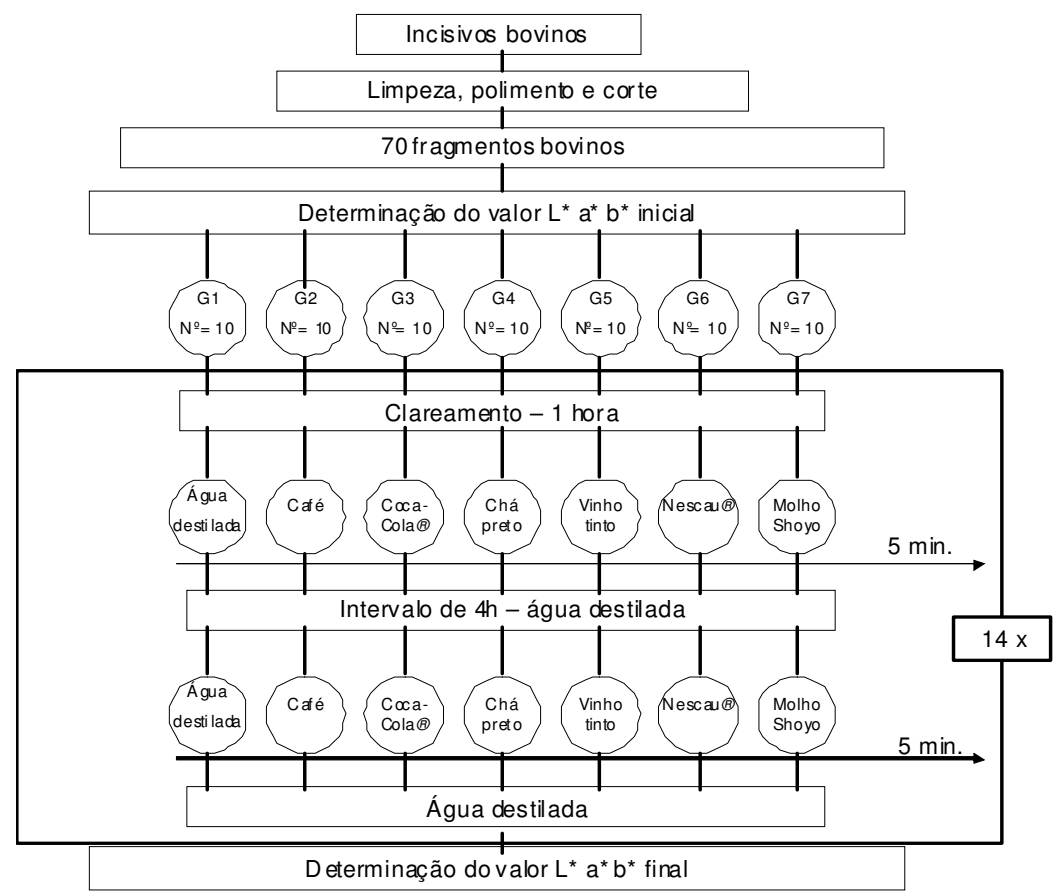

Figure 1. Study design.

Sample calculation; For this study, the sample size was estimated using the statistical software $\mathrm{G} *$ Power, using as means and standard deviation obtained from the pilot study resulting in 10 samples per group.

\section{Preparation and treatment of the specimens}

Seventy sound bovine incisors were stored in $0.1 \%$ thymol solution after collection and disinfection. These teeth were examined under a magnifying glass to discover the presence of any gaps, cracks or caries. If any of these features were found, the tooth was discarded and replaced. The defect-free teeth were stored in distilled water at 7 ${ }^{\circ} \mathrm{C}$ until required.

The crowns were separated from their roots by sectioning at the dentine-enamel junction with a double-faced diamond disk (KG Sorensen, Ind. Com. Ltda, Barueri, SP, Brazil) using a low-speed handset with constant water irrigation. The crown was sectioned with a precision, slow-speed, watercooled diamond saw (Extec4" x $012 \times 1 / 2$ ) to obtain dental slabs, presenting $5 \mathrm{~mm} \times 5 \mathrm{~mm}$. Each specimen, with the labial surface exposed, was individually submerged in chemically cured acrylic resin. After preparation, the samples were polished, using pumice and water for 40 seconds at lowspeed.

These specimens were stored in distilled water and divided into seven groups $(n=10)$, in accordance with the staining solutions as follows: distilled water; coffee (Nescafé solúvel Dolca ${ }^{\circledR}$, Nestlé Brasil Ltda, SP, Brazil); cola (Coca-Cola®, Coca- Cola Brasil, SP, Brazil); tea (Matte Leão®/Tradicional, Coca- Cola Brasil, RJ, Brazil); red wine (Quinta do Morgado®, Fante Indústria de Bebidas Ltda, Rio Grande do Sul, Brazil); chocolate milk (Nescau ${ }^{\circledR}$, Nestlé Brasil Ltda, SP, Brazil); and soya sauce (Shoyu) (Sakura®, SakuraNakaya Alimentos Ltda, SP, Brazil). The coffee was prepared according to the manufacturer's instructions - $4 \mathrm{~g}$ of coffee dissolved in $200 \mathrm{ml}$ of boiling water.

After (24 hours), the initial color of the untreated enamel samples was determined and assessed according to the Commission 
Internationale de l'Eclariage (CIE) L*a*b* system, using a spectrophotometer (Minolta CR-321, Japan).

For the dental bleaching, 22\% carbamide peroxide (WhitenessPerfect, FGM, Santa Catarina, Brazil) was applied on each sample surface with a syringe, to form a $1 \mathrm{~mm}$-thick-layer. The dental bleaching was repeated for 14 consecutive days. After 1 hour, the bleaching agent was removed and the samples were washed with distilled water and immersed in $20 \mathrm{ml}$ of staining solution for 5 minutes, at $37^{\circ} \mathrm{C}$ and $100 \mathrm{rpm}$ (Termoagitador TE420, Tecnal, Brazil) and subsequent washing and immersing in distilled water for 4 hours, at $37^{\circ} \mathrm{C}$ and $100 \mathrm{rpm}$. This staining procedure of staining was repeated on a daily basis for a total of two times per day.

The final color evaluation of all groups was performed at 14 days after the staining procedures.
Color change $\left(\Delta \mathrm{E}^{*} \mathrm{ab}\right)$ was calculated by the equation: $\Delta \mathrm{E}^{*} \mathrm{ab}=\left[\left(\Delta \mathrm{L}^{*}\right) 2+\left(\Delta \mathrm{a}^{*}\right) 2+\left(\Delta \mathrm{b}^{*}\right) 2\right] 1 / 2$, where $\Delta \mathrm{L}^{*}, \Delta \mathrm{a}^{*}$ and $\Delta \mathrm{b}^{*}$ are the differences in the respective values before and after staining.

\section{Statistical Analysis}

The data obtained was statistically analyzed using One-way analysis of variance (ANOVA) and Tukey tests, applied at a significant level of 0.05 for color assessment.

\section{RESULTS}

Tooth shade means and tooth color parameters $\left(\Delta \mathrm{L}^{*}, \Delta \mathrm{a}^{*}, \Delta \mathrm{b}^{*}, \Delta \mathrm{E}^{*}\right)$ for all of the groups are presented in Table 1 .

Table 1. Tooth shade means for the different treatment groups.

\begin{tabular}{ccccc}
\hline & $\Delta \mathrm{L}^{*}$ & $\Delta \mathrm{a}^{*}$ & $\Delta \mathrm{b}^{*}$ & $\Delta \mathrm{E}^{*}$ \\
\hline Distilled water & 3.92 & -0.21 & -3.32 & 5.31 \\
Coffee & 0.17 & -0.39 & 6.80 & 6.93 \\
Cola & 1.00 & -0.53 & 4.97 & 6.40 \\
Tea & 0.94 & -0.76 & 2.97 & 4.36 \\
Red wine & 2.12 & 1.23 & -2.58 & 4.09 \\
Chocolate milk & 1.50 & -0.32 & -3.70 & 4.49 \\
Shoyu & -0.06 & -0.48 & 7.52 & 8.15 \\
\hline
\end{tabular}

The effectiveness of the dental bleaching was confirmed by the mean $\Delta \mathrm{E}$ value for all bleached teeth. The comparison performed between groups showed that the group exposed to Shoyu had higher $\Delta \mathrm{E}$ when compared to the control group exposed to distilled water and the groups exposed to tea, red wine and chocolate milk (Figure 2).

After bleaching, the pigmentation of the teeth had decreased ( $a^{*}$ decreased - less red color - showing a negative $\Delta \mathrm{a}^{*}$ value; $\mathrm{b}^{*}$ decreased - less yellow color - showing a negative $\Delta \mathrm{b}^{*}$ value; and $\mathrm{L}^{*}$ - brightness - increased with a positive $\Delta \mathrm{L}^{*}$ value) for the group using distilled water and chocolate milk. A decrease in luminosity (negative value of $\Delta \mathrm{L}^{*}$ ) occurred when the teeth were exposed to Shoyu.

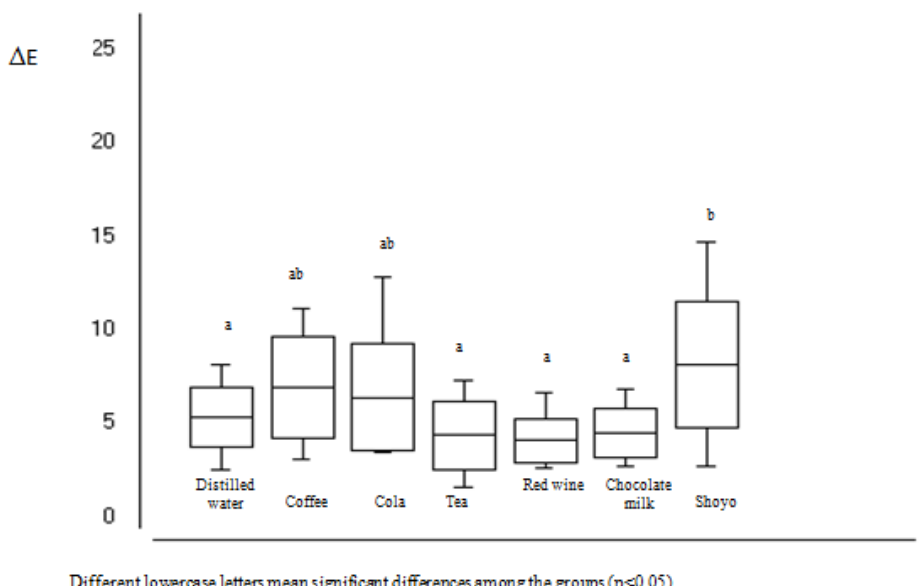

Figure 2. Means value of $\Delta \mathrm{E}$ as a function of staining solution. 


\section{DISCUSSION}

Bleaching effects must be monitored on time scales, at least during the period of at least one year of one year to be significant (ALTARAKEMAH; DARVELL, 2016), thus evaluating the efficacy of the products used, as the possible agents that interfere with the longevity of dental bleaching treatment. However, few studies (KARADAS; SEVEN, 2014. PIROLO et al., 2014. CÔRTES et al., 2013. LIPORONI et al., 2010. ATTIA et al., 2009) were prepared to analyze this fact.

Research indicates that the loss or denaturation of enamel proteins causes increased surface roughness (ZIMMERMAN et al., 2010). This coupled with other factors, such as: enamel composition, water absorption rate, permeability changes and irregularities on the enamel after the dental bleaching procedure may be responsible for the recurrence of extrinsic staining (HEGEDUS et al., 1999. ROTSTEIN et al., 1996). In the case of dental bleaching, enamel remineralization (CÔRTES et al., 2013) as well as the use of fluorine, fractionated $\mathrm{CO}_{2}$ laser and nanohidroxiapatita are suggested at the end of the bleaching treatment in order to prevent absorption of spots and increase enamel hardness (MOOSAVI; DARVISHZADEH, 2016).

The overall tooth color change results showed that the exposure of dental fragments to Shoyu during dental bleaching resulted in a $\Delta \mathrm{E}$ that was different only from the control group. Similar results were not found in the literature, since the studies have limited most of these investigations to a few staining agents (BRISO et al., 2016. MATIS et al. 2015. KARADAS; SEVEN, 2014. PIROLO et al., 2014. CÔRTES et al., 2013. LIPORONI et al., 2010. ATTIA et al., 2009). However, all of the bleached study groups presented similar color alterations at the end of treatment.

A previous report affirms that immersion among in the pigmented solutions (coffee, wine and cola-based soda) during the dental bleaching treatment does not affect the outcome of treatment (CANEPPELE et al., 2009). These results are consistent with other studies (BRISO et al., 2016. MATIS et al. 2015) which reported that dark beverages do not negatively influence the overall tooth color change final values.

On the other hand, according to Côrtes et al. (2013) the pigmented agents wine and coffee were able to promote color changes on the surface of the enamel. However, wine led to increased pigmentation when compared to coffee. Similar results were recently reported by Karadas and Seven (2014), who noted that there a greater change in color on teeth immersed in wine, tea and cola solutions, although no significant difference was observed between the control and coffee groups.

For Liporoni et al. (2010), enamel bleached with $35 \%$ hydrogen peroxide was susceptible to the pigmentation of wine, but coffee does not interfere with the whitening process. The authors report the possibility that hydrogen peroxide is a facilitator for this pigmentation, due to the increased porosity of the enamel surface. In addition, the acidity of wine and the presence of ethanol enhance the demineralization of the enamel surface, increasing vulnerability to staining. Based on data obtained in this study, the exposure of dental fragments to wine and coffee presented similar color alterations.

The $\Delta \mathrm{a}^{*}$ analysis showed that specimens treated with wine presented a more reddish color than other groups due to the dye used in these substances. Consequently, the dental bleaching was not fully effective in breaking down those pigment molecules. On the other hand, $\Delta b^{*}$ negative values were obtained for groups immersed in distilled water, red wine and chocolate milk, resulting in a less yellow coloration. This is due to the breaking of their complex chains through dental bleaching, making the samples more blue (KAWAMOTO; TSUJIMOTO, 2004).

In the present study, bovine teeth were used, as they are easy to obtain and standardize, and due to their uniform composition, similar to human teeth with respect to morphology and histology (WIEGAND et al., 2005). However, teeth with chronological ages and degrees of distinct mineralization were used, as well as different thicknesses of dental substrates. This fact may explain the results obtained with regard to pigmentation, since surface roughness and nonuniform geometry can influence the results (CÔRTES et al., 2013). Furthemore, some studies have reported that the acidic $\mathrm{pH}$ of pigment solutions promotes a loss of mineral in tooth structure, favoring the penetration of these solutions into the demineralized structure (MESQUITAGUIMARÃES et al., 2015. ZANET et al., 2011), and others containing ethanol or pigments (BERGER et al., 2008). This influences the overall tooth color change during the bleaching treatment.

Differences in the results of different studies can be justified by the exposure time to bleaching agents, which leads to a tendency to variable effects of pigmented agents (LIPORONI et al., 2010). Furthermore, the action of carbamide peroxide and color stability differs significantly from hydrogen 
peroxide (LIMA et al., 2009). Another factor to be considered is the $\mathrm{pH}$ of the bleaching agent, since the effectiveness of hydrogen peroxide is directly proportional to the $\mathrm{pH}$ increase (TORRES et al., 2014). The present study may contribute to the understanding of the mechanisms of pigmentation during dental bleaching, but it is known that other factors as mentioned above also influence bleaching procedures. Therefore, further investigations are recommended considering these factors and optical properties of the substrate.

\section{CONCLUSION}

Based on these results, it is concluded that all the substances tested with potential pigment in this study encouraged color change of dental substrate. However, bleached enamel was susceptible to staining with soya sauce (Shoyu), while other substances do not interfere with bleaching treatment.

RESUMO: A estabilidade de cor conseguida por meio do clareamento dental pode ser afetada pela exposição à agentes pigmentantes presentes nos alimentos. Contudo, há uma escassa investigação sobre o manchamento dos dentes durante o clareamento dental. Este estudo investigou o efeito de agentes pigmentantes sobre a estabilidade da cor dos dentes durante o clareamento dental. Os blocos obtidos a partir de incisivos bovinos foram divididos em sete grupos $(\mathrm{n}=$ 10) de acordo com os agentes pigmentantes (água destilada - controle - café, cola, chá, vinho tinto, leite achocolatado e molho de soja - shoyu. A cor foi avaliada com um espectrofotômetro (Minolta CR-321, Japão) antes e após o clareamento $\left(1^{\circ}\right.$ e $14^{\circ}$ dias), utilizando o sistema (CIE) L*a*b*. O procedimento de clareamento dental foi realizado usando gel de peróxido de carbamida a 22\% aplicado à superfície da amostra por um período de 1 hora por dia, durante 14 dias. Após o clareamento, os dentes foram expostos a $20 \mathrm{ml}$ da solução pigmentante por 5 minutos, $37^{\circ} \mathrm{C}$ e $100 \mathrm{rpm}$ em diferentes períodos. Durante o experimento, as amostras foram armazenadas em água destilada. Os dados foram analisados por meio do teste ANOVA, seguido do Tukey, com nível de significância de 5\%. Foram observadas diferenças significativas para os valores de $\Delta \mathrm{E}^{*}(\mathrm{p}<0,05)$ entre os grupos. $\mathrm{O}$ grupo Shoyu apresentou uma diminuição na luminosidade (valor negativo de $\left.\Delta \mathrm{L}^{*}\right)$. Pode-se concluir que todas as soluções que continham pigmentos promoveram manchamento superficial. No entanto, o esmalte clareado foi susceptível apenas ao manchamento com molho de soja (Shoyu), enquanto outras substâncias não interferiram no tratamento de clareamento dental.

PALAVRAS-CHAVE: Materiais dentários. Cor. Pigmentação. Clareamento dental. Espectrofotometria.

\section{REFERENCES}

AL-TARAKEMAH, Y.; DARVELL, B. W. On the permanence of tooth bleaching. Dent Mater. v. 32, n. 10, p. 1281-8, 2016. https://doi.org/10.1016/j.dental.2016.07.008

ATTIA, M. L.; AGUIAR, F. H.; MATHIAS, P.; AMBROSANO, G. M.; FONTES, C. M.; LIPORONI, P. C. The effect of coffee solution on tooth color during home bleaching applications. Am J Dent. v. 22, n. 3, p. 175$9,2009$.

BASTING, R. T.; AMARAL, F. L.; FRANCA, F. M.; FLORIO, F. M. Clinical comparative study of the effectiveness of and tooth sensitivity to $10 \%$ and $20 \%$ carbamide peroxide home-use and $35 \%$ and $38 \%$ hydrogen peroxide in-office bleaching materials containing desensitizing agents. Oper Dent. v. 37, n. 5, p. 464-73, 2012. https://doi.org/10.2341/11-337-C

BEDDIS, H. P.; NIXON, P. J. Layering composites for ultimate aesthetics in direct restorations. Dent Update. v. 39, n. 9, p. 630-2, 634-6, 2012.

BERGER , S. B.; COELHO, A. S.; OLIVEIRA, V. A.; CAVALLI, V.; GIANNINI, M. Enamel susceptibility to red wine staining after 35\% hydrogen peroxide bleaching. J Appl Oral Sci. v. 16, n, 3, p. 201-4, 2008. https://doi.org/10.1590/S1678-77572008000300007

BRISO, A. L.; FAGUNDES, T. C.; GALLINARI, M. O.; MOREIRA, J. ALMEIDA, L.; RAHAL, V.; GONÇALVES, R. S.; SANTOS, P. D. An in situ study of the influence of staining beverages on color alteration of bleached teeth. Oper Dent. v. 41, n. 6, p. 627-33, 2016. https://doi.org/10.2341/15-306-L 
CANEPPELE, T. M. F.; SOUZA, A. C.; VALERA, M. C.; PAGANI, C. Influência da embebição dental em substâncias com corantes na eficácia do clareamento dental com peróxido de carbamida. Arquivos em Odontologia. v. 45, n. 4, p. 171-7, 2009.

CÔRTES, G.; PINI, N. P.; LIMA, D. A.; LIPORONI, P. C.; MUNIN, E.; AMBROSANO, G. M.; AGUIAR, F. H.; LOVADINO, J. R. Influence of coffee and red wine on tooth color during and after bleaching. Acta Odontol Scand. v. 71, n. 6, p. 1475-80, 2013. https://doi.org/10.3109/00016357.2013.771404

DEY, S.; PANDEY, V.; KUMAR, A.; AWASTHI, N.; SAHU, A.; PUJARI, S. C. In vitro comparison of impact of different bleaching agents on the microhardness of enamel. J Contemp Dent Pract. v. 17, n. 3, p. 258-62, 2016. https://doi.org/10.5005/jp-journals-10024-1837

DE ABREU, D. R.; SASAKI, R. T.; AMARAL, F. L.; FLÓRIO, F. M.; BASTING, R. T. Effect of home-use and in-office bleaching agents containing hydrogen peroxide associated with amorphous calcium phosphate on enamel microhardness and surface roughness. J Esthet Restor Dent. v. 23, n. 3, p. 158-68, 2011. https://doi.org/10.1111/j.1708-8240.2010.00394.x

HEGEDUS, C.; BISTEY, T.; FLORA-NAGY, E.; KESZTHELYI, G.; JENEI, A. An atomic force microscopy study on the effect of bleaching agents on enamel surface. J Dent. v. 27, n. 7, p. 509-15, 1999. https://doi.org/10.1016/S0300-5712(99)00006-8

JOINER, A. Tooth colour: a review of the literature. J Dent. v. 32, suppl 1, p. 3-12, 2004. https://doi.org/10.1016/j.jdent.2003.10.013

JOSEY, A. L.; MEYERS, I. A.; ROMANIUK, K.; SYMONS, A. L. The effect of a vital bleaching technique on enamel surface morphology and the bonding of composite resin to enamel. J Oral Rehabil. v. 23, n. 4, p. 244-50, 1996. https://doi.org/10.1111/j.1365-2842.1996.tb00848.x

KARADAS, M.; SEVEN, N. The effect of different drinks on tooth color after home bleaching. Eur J Dent. v. 8, n. 2, p. 249-53, 2014. https://doi.org/10.4103/1305-7456.130622

KAWAMOTO, K.; TSUJIMOTO, Y. Effects of the hydroxyl radical and hydrogen peroxide on tooth bleaching. J Endod. v. 30, n. 1, p. 45-50, 2004. https://doi.org/10.1097/00004770-200401000-00010

LIA MONDELLI, R. F.; GARRIDO GABRIEL, T. R.; PIOLA RIZZANTE, F. A.; MAGALHÃES, A. C.; SOARES BOMBONATTI, J. F.; ISHIKIRIAMA, S. K. Do different bleaching protocols affect the enamel microhardness?. Eur J Dent. v. 9, n. 1, p. 25-30, 2015. https://doi.org/10.4103/1305-7456.149634

LIMA, D. A.; AGUIAR, F. H.; LIPORONI, P. C.; MUNIN, E.; AMBROSANO, G. M.; LOVADINO, J. R. In vitro evaluation of the effectiveness of bleaching agents activated by different light sources. J Prosthodont. v. 18, n. 3, p. 249-54, 2009. https://doi.org/10.1111/j.1532-849X.2008.00420.x

LIMA, D. A.; AGUIAR, F. H.; LIPORONI, P. C.; MUNIN, E.; AMBROSANO, G. M.; LOVADINO, J. R. Influence of chemical or physical catalysts on high concentration bleaching agents. Eur J Esthet Dent. v. 6, $\mathrm{n}$. 4, p. 454-66, 2011.

LIPORONI, P. C.; SOUTO, C. M.; PAZINATTO, R. B.; CESAR, I. C.; REGO, M. A.; MATHIAS, P.; CAVALLI, V. Enamel susceptibility to coffee and red wine staining at different intervals elapsed from bleaching: a photoreflectance spectrophotometry analysis. Photomed Laser Surg. v. 28, suppl 2, p. S105-9, 2010. https://doi.org/10.1089/pho.2009.2627

MATIS, B. A.; WANG, G.; MATIS, J. I.; COOK, N. B.; ECKERT, G. J. White diet: Is it necessary during tooth whitening?. Oper Dent. v. 40, n. 3, p. 235-40, 2015. https://doi.org/10.2341/14-019-LIT 
MESQUITA-GUIMARÃES, K. S.; SCATENA, C.; BORSATTO, M. C.; RODRIGUES-JÚNIOR, A. L.; SERRA, M. C. Effect of foods and drinks on primary tooth enamel after erosive challenge with hydrochloricacid. Braz Oral Res. v. 29, n. 1, p. 1-7, 2015. https://doi.org/10.1590/1807-3107BOR2015.vol29.0096

ZANET, C. G.; FAVA, M.; ALVES, L. A. In vitro evaluation of the microhardness of bovine enamel exposed to acid solutions after bleaching. Braz Oral Res. v. 25, n. 6, p. 562-7, 2011. https://doi.org/10.1590/S180683242011000600015

MOOSAVI, H; DARVISHZADEH F. The Influence of Post Bleaching Treatments in Stain Absorption and Microhardness. Open Dent J. v. 10, p. 69-78, 2016. https://doi.org/10.2174/1874210616021000069

NATHOO, S. A. The chemistry and mechanisms of extrinsic and intrinsic discoloration. J Am Dent Assoc. v. 128, suppl: 6S-10S, 1997. https://doi.org/10.14219/jada.archive.1997.0428

PAOLONE, G.; SARACINELLI, M.; DEVOTO, W.; PUTIGNANO, A. Esthetic direct restorations in endodontically treated anterior teeth. Eur J Esthet Dent. v. 8, n. 1, p. 44-67, 2013.

PIROLO, R.; MONDELLI, R. F.; CORRER, M.; GONZAGA, C. C.; FURUSE, A. Y. Effect of coffee and a cola-based soft drink on the color stability of bleached bovine incisors considering the time elapsed after bleaching. J Appl Oral Sci. v. 22, n. 6, p. 534-40, 2014. https://doi.org/10.1590/1678-775720130578

ROTSTEIN, I.; DANKNER, E.; GOLDMAN, A.; HELING, I.; STABHOLZ, A.; ZALKIND, M. Histochemical analysis of dental hard tissues following bleaching. J Endod. v. 22, n. 1, p. 23-5, 1996. https://doi.org/10.1016/S0099-2399(96)80231-7

SPALDING, M.; TAVEIRA, L. A.; DE ASSIS, G. F. Scanning electron microscopy study of dental enamel surface exposed to $35 \%$ hydrogen peroxide: alone, with saliva, and with $10 \%$ carbamide peroxide. J Esthet Restor Dent. v. 15, n. 3, p. 154-64, discussion 165, 2003.

TORRES, C. R. G.; CRASTECHINI, E.; FEITOSA, F. A.; PUCCI, C. R.; BORGES, A. B. Influence of pH on the Effectiveness of Hydrogen Peroxide Whitening. Oper Dent. v. 39, n. 6, p. E261-8, 2014. https://doi.org/10.2341/13-214-L

WIEGAND, A.; VOLLMER, D.; FOITZIK, M.; ATTIN, R.; ATTIN, T. Efficacy of different whitening modalities on bovine enamel and dentin. Clin Oral Investig. v. 9, n. 2, p. 91-7, 2005.

https://doi.org/10.1007/s00784-004-0291-2

ZIMMERMAN, B.; DATKO, L.; CUPELLI, M.; ALAPATI, S.; DEAN, D.; KENNEDY, M. Alteration of dentin-enamel mechanical properties due to dental whitening treatments. J Mech Behav Biomed Mater. v. 3, n. 4, p. 339-46, 2010. https://doi.org/10.1016/j.jmbbm.2010.01.005 